\title{
Integrated bioconversion of pulp and paper primary sludge to second generation bioethanol using Saccharomyces cerevisiae ATCC 26602
}

\author{
Cátia V.T. Mendes ${ }^{a}$, Crispin H.G. Cruz ${ }^{b}$, Diana F.N. Reis ${ }^{a}$, M. Graça V.S. Carvalho ${ }^{\text {a }}$, Jorge M.S. Rocha ${ }^{a}, *$ \\ ${ }^{a}$ CIEPQPF, Department of Chemical Engineering, Faculty of Sciences and Technology, University of Coimbra, Pólo II, Rua Sílvio Lima, $3030-790$ Coimbra, Portugal

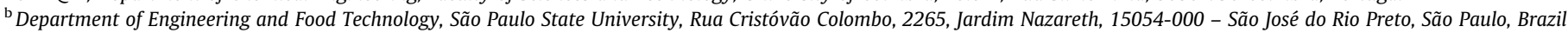

\section{H I G H L I G H T S}

- Primary sludge from pulp industry can be valorized instead of landfilling.

- Primary sludge can be converted to ethanol by SSF without pre-

treatment.

- The enzyme dosage was significantly reduced from 35 to $15 \mathrm{FPU} \mathrm{g}_{\mathrm{CH}}{ }^{-1}$.

- Despite mixing difficulties the performance of batch SSF was better than fed-batch.

- High solids content of $21.7 \%$, rarely found in literature were successfully used.

\section{A R T I C L E I N F O}

\section{Article history:}

Received 22 June 2016

Received in revised form 29 July 2016

Accepted 30 July 2016

Available online 3 August 2016

\section{Keywords:}

Bioethanol

Primary sludge

Simultaneous saccharification and

fermentation

Unbleached pulp

\section{G R A P H I C A L A B S T R A C T}

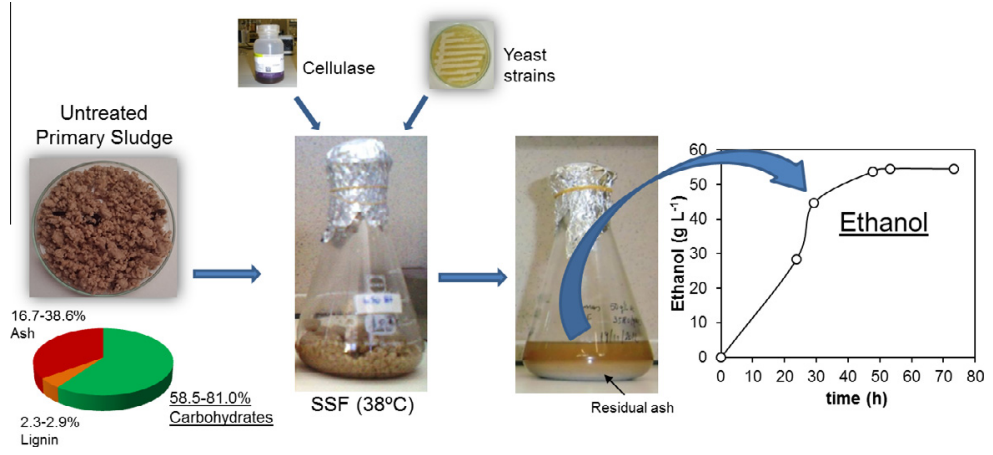

\section{A B S T R A C T}

Primary sludge, from different pulp and paper mills, was used as feedstock in simultaneous saccharification and fermentation (SSF) processes to produce ethanol. SSF was carried out with Saccharomyces cerevisiae ATCC 26602 yeast and NS 22192 enzymatic extract using $150 \mathrm{~g} \mathrm{~L}^{-1}$ of carbohydrates (CH) from primary sludge. The effect of sterilization, reduction of enzyme dosage and fed-batch $v s$. batch conditions were studied. The removal of sterilization can be considered since no contamination or atypical byproducts were observed, although SSF efficiency slightly decreased. The reduction of the enzyme dosage from 35 to $15 \mathrm{FPU} \mathrm{g}_{\mathrm{CH}}^{-1}$ was successful. Despite of initial mixing difficulties, batch SSF enabled higher ethanol concentration (41.7 $\left.\mathrm{g} \mathrm{L}^{-1}\right)$, conversion yield (48.9\%) and productivity $\left(0.78 \mathrm{~g} \mathrm{~L}^{-1} \mathrm{~h}^{-1}\right)$, compared to the fed-batch process at the same conditions of low enzyme dosage of $5 \mathrm{FPU} \mathrm{g}_{\mathrm{CH}}^{-1}$ and high solids content of $21.7 \%$, rarely found in literature.

Published by Elsevier Ltd.

\section{Introduction}

Pulp mills are established biorefineries since they use forest biomass to produce chemicals, materials, energy and heat. This industrial activity generates a high amount of lignocellulosic solid

\footnotetext{
* Corresponding author.

E-mail addresses: catvan@eq.uc.pt (C.V.T. Mendes), crispin@ibilce.unesp.br (C.H.G. Cruz), di.jesse@gmail.com (D.F.N. Reis), mgc@eq.uc.pt (M. Graça V.S Carvalho), jrocha@eq.uc.pt (J.M.S. Rocha).
}

wastes, such as primary sludge. This solid residue consists of short lignocellulosic fibers lost along the pulp and paper production line. Instead of incinerating, discharging or using it in composting, primary sludge can be valorized. Its high carbohydrate content, cellulose and hemicelluloses, can be converted to different value-added products (e.g. bioethanol) through biotechnological routes (Ballesteros et al., 2002; Park et al., 2004; Budhavaram and Fan, 2009; Zhang and Lynd, 2010; Balat, 2011; Lin et al., 2012; Cavka et al., 2014; Guan et al., 2016). This process integration maximizes the use of forest biomass, allows the reduction of operation costs, 
increases the products competitiveness and diversifies the products portfolio.

For the bioconversion of this pre-delignified biomass to bioethanol, an enzymatic hydrolysis step is needed to degrade carbohydrates into fermentable monosaccharides followed by their fermentation and finally by ethanol recovery. Separate hydrolysis and fermentation (SHF) and simultaneous saccharification and fermentation (SSF) are usually used in bioethanol production. The main advantage of SSF is the use of a single reaction vessel, whilst the main disadvantage is the difference between the optimal temperatures for hydrolysis and for fermentation. The search of a robust ethanologenic microorganism, able of fermenting both hexoses and pentoses as well as tolerant to ethanol, is a challenge. In addition, ethanol concentration must be higher than $40 \mathrm{~g} \mathrm{~L}^{-1}$ to render distillation economically feasible. Therefore, high ethanol concentration must be achieved, namely by increasing the carbohydrate concentration. However, the resulting high solids content can lead to stirring problems or substrate inhibition. These drawbacks can be overcome by using a fed-batch process which is achieved by intermittent feeding of the substrate to the bioreactor (Ballesteros et al., 2002; Cardona et al., 2015).

Primary sludge also contains a high amount of ash, mostly calcium carbonate, which can hinder the bioconversion process of the cellulosic fibers. $\mathrm{CaCO}_{3}$ increases $\mathrm{pH}$ value of primary sludge (8-10), which is higher than the optimum $\mathrm{pH}$ for cellulase activity $(\sim 5)$. Acid pretreatments have been used, in SHF and SSF processes, to neutralize $\mathrm{CaCO}_{3}$ (Fan and Lynd, 2007; Marques et al., 2008; Li et al., 2009; Kang et al., 2010; Wang et al., 2011; Mendes et al., 2014; Gurram et al., 2015). However, the chemical pretreatment with acids releases $\mathrm{CO}_{2}$, an environmental inconvenience in the process. Other alternatives have been proposed in earlier studies to remove $\mathrm{CaCO}_{3}$ not as effective as the acid pretreatment (Mendes et al., 2014). SSF process can be applied directly to primary sludge without any pretreatment, in order to alleviate this problem. During the integrated fermentation, carbonic and other organic acids are produced, which can partially neutralize $\mathrm{CaCO}_{3}$, acting afterwards as a buffer to stabilize $\mathrm{pH}$, promoting carbohydrates hydrolysis to fermentable sugars (Kang et al., 2010; Dwiarti et al., 2012; Guan et al., 2016). Since enzymatic hydrolysis and fermentation occurred at different optimal temperatures, compatible conditions and an appropriate microorganism must be selected (Ballesteros et al., 2004; Olofsson et al., 2008; Ferreira et al., 2010). The yeast Saccharomyces cerevisiae has a great biotechnological tradition in baking, brewing and wine production. A profound knowledge of genetics, physiology, biochemistry, fermentative technology and genetic engineering of this yeast has been gathered (Barnett, 2003; Nevoigt, 2008). The present work studies the energetic valorization of primary sludge from different Portuguese pulp and paper mills. Untreated primary sludge was used as raw-material to produce bioethanol by SSF with Saccharomyces cerevisiae ATCC 26602. Additionally, unbleached pulp was used as reference material because of its similar organic composition and almost absence of ash, in comparison to primary sludge.

\section{Materials and methods}

\subsection{Lignocellulosic biomass}

Primary sludge was provided by three pulp and paper mills from the Centre Region of Portugal, designed here by A, B and C. The chemical composition of the different primary sludge samples was determined. Total solids, carbohydrates, lignin and ash contents were analyzed, according to NREL standard protocols (NREL, 2008). $\mathrm{CaCO}_{3}$ was also estimated by incineration and gravimetric evaluation. Moreover, unbleached pulp (reference material) was also characterized.

\subsection{Enzymes}

The enzymatic extract NS 22192 (kindly provided by Novozymes, Denmark) was used in the saccharification of the carbohydrates from primary sludge. NS 22192 consisted of cellulases, $\beta$ glucosidases and hemicellulases. The optimal temperature and $\mathrm{pH}$ range for maximum enzymatic activity was $45-50{ }^{\circ} \mathrm{C}$ and $5.0-5.5$, respectively. The cellulase activity of this enzymatic extract was determined for 38,42 and $50^{\circ} \mathrm{C}$, according to NREL standard procedure (NREL, 2008).

\subsection{Microorganisms}

SSF processes of primary sludge and unbleached pulp were carried out with Saccharomyces cerevisiae ATCC 26602 yeast (American Type Culture Collection, Virginia, USA). A fresh inoculum was previously prepared, using $100 \mathrm{~mL}$ of culture medium consisted of $10 \mathrm{~g} \mathrm{~L}^{-1}$ glucose, $5 \mathrm{~g} \mathrm{~L}^{-1}$ peptone, $3 \mathrm{~g} \mathrm{~L}^{-1}$ malt extract, $3 \mathrm{~g} \mathrm{~L}^{-1}$ yeast extract. The yeast kinetic growth was analyzed at 30,38 and $42{ }^{\circ} \mathrm{C}$. For each temperature used, S. cerevisiae ATCC 26602 was gradually adapted (performing successive cultures) from its optimal temperature $\left(30^{\circ} \mathrm{C}\right)$ until the final goal temperature $(38$ or $42^{\circ} \mathrm{C}$ ). Yeast growth was evaluated for $8 \mathrm{~h}$ and by spectrophotometry, measuring the cell density at $540 \mathrm{~nm}$ each $30 \mathrm{~min}$.

\subsection{SSF experiments}

SSF of primary sludge or unbleached pulp were carried out in $250 \mathrm{~mL}$ Erlenmeyer flasks with $100 \mathrm{~mL}$ of working volume. A fedbatch strategy was first applied: a carbohydrate concentration of $50 \mathrm{~g} \mathrm{~L}^{-1}$ was initially used followed by two more carbohydrate additions (equivalent to $50 \mathrm{~g} \mathrm{~L}^{-1}$ each), after 24 and $\sim 54 \mathrm{~h}$. Therefore, a total of $150 \mathrm{~g} \mathrm{~L}^{-1}$ of carbohydrates was supplied. Solutions containing a glucose supplement $\left(5 \mathrm{~g} \mathrm{~L}^{-1}\right)$, nutrients $\left(5 \mathrm{~g} \mathrm{~L}^{-1}\right.$ peptone, $3 \mathrm{~g} \mathrm{~L}^{-1}$ malt extract, $3 \mathrm{~g} \mathrm{~L}^{-1}$ yeast extract) and $S$. cerevisiae ATCC 26602 fresh inoculum (10\% of working volume) were added. An enzyme dosage of $35 \mathrm{FPU} \mathrm{g}_{\mathrm{CH}}^{-1}$ (filter paper unit per gram of carbohydrate) was used concerning the carbohydrate content added at $\mathrm{t}=0 \mathrm{~h}$ and according to the supplier guidelines. All the materials and solutions were sterilized before SSF, except for the enzymatic extract solution. The Erlenmeyer flasks were kept at $38^{\circ} \mathrm{C}$ and $150 \mathrm{rpm}$. Some operation conditions were tested along the work: i) absence of sterilization; ii) absence of a glucose supplement; iii) minimization of enzyme dosage ( 35 to $5 \mathrm{FPU} \mathrm{g} \mathrm{g}_{\mathrm{CH}}^{-1}$ were tested, always referred to $\mathrm{t}=0 \mathrm{~h}$ ) and iv) SSF in batch conditions with high initial solids (a total of $150 \mathrm{~g} \mathrm{~L}^{-1}$ of carbohydrates initially charged, with 5 or 15 FPU g $\mathrm{g}_{\mathrm{CH}}^{-1}$ of NS 22192).

Fermentation controls (without lignocellulosic material) were also performed in order to eliminate the contribution of external sugars (from the enzyme, the inoculum and supplements solutions) in the production of ethanol.

\subsection{Analytical methods for SSF samples}

Samples were withdrawn from the SSF cultures and centrifuged. Reducing sugars were analyzed by the modified colorimetric DNS method (NREL, 2008). Glucose, xylose, ethanol and by-products were evaluated by high performance liquid chromatography (HPLC), after samples filtration through a $0.2 \mu \mathrm{m}$ syringe filter membrane (Whatman). Components were analyzed with an Agilent Hi-Plex Ca $(8 \mu \mathrm{m} \times 300 \mathrm{~mm})$ column maintained at 80 $85^{\circ} \mathrm{C}$. HPLC system included a Knauer model K-301 with a refractive index (RI) detector. 
Ethanol yield (Y) was calculated by Eq. (1), where: $[\mathrm{EtOH}]_{\mathrm{t}}$ is the ethanol concentration $\left(\mathrm{g}_{\mathrm{EtOH}} \mathrm{L}^{-1}\right)$ at time $\mathrm{t}(\mathrm{h}) ; f$ is the carbohydrates fraction in dry weight lignocellulosic biomass (DWB) $\left(\mathrm{g}_{\mathrm{CH}}-\right.$ $\mathrm{g}_{\mathrm{DWB}}^{-1}$ ); [Biomass] is the concentration of dry weight lignocellulosic feedstock, total added until the time of ethanol evaluation, for fedbatch operation or initial in batch operation $\left(g_{\text {DWB }} L^{-1}\right)$; and 0.568 is the global and theoretical mass conversion factor of carbohydrates to ethanol $\left(\mathrm{g}_{\mathrm{EtOH}} \mathrm{g}_{\mathrm{CH}}^{-1}\right)$. Ethanol productivity $(\mathrm{P})$ was determined according to Eq. (2) (NREL, 2008; Faga et al., 2010). SSF experiments were carried out in duplicates. Average values and standard deviations are presented in the following tables.

$\mathrm{Y}(\%)=\frac{[\mathrm{EtOH}]_{\mathrm{t}}}{0.568 \times \mathrm{f} \times[\text { Biomass }]} \times 100$

$\mathrm{P}\left(\mathrm{gL}^{-1} \mathrm{~h}^{-1}\right)=\frac{[\mathrm{EtOH}]_{\mathrm{t}}}{\mathrm{t}}$

\section{Results and discussion}

\subsection{Chemical composition of lignocellulosic materials}

Table 1 shows the chemical composition of the primary sludge collected from three different pulp and paper mills (A, B and C) and the unbleached pulp used in this work as reference material. The lignin content is similar among the three primary sludge samples, showing major differences in solids, ash and carbohydrates contents. Unbleached pulp is used as reference material, since it has analogous lignin content and a very small ash amount.

\subsection{Cellulase activity of enzymatic extract NS 22192}

The enzymatic activity (cellulase activity) of NS 22192, based on the filter paper assay, was determined at different temperatures, 38,42 and $50{ }^{\circ} \mathrm{C}$. A cellulase activity of $123.3 \mathrm{FPU} \mathrm{mL}{ }^{-1}$ was obtained at its optimal temperature $\left(50^{\circ} \mathrm{C}\right)$. Cellulase activity decreased to 102.8 and $46.8 \mathrm{FPU} \mathrm{mL}^{-1}$, respectively, at 42 and $38^{\circ} \mathrm{C}$.

\subsection{S. cerevisiae ATCC 26602 growth at different temperatures}

The optimal temperature for S. cerevisiae ATCC 26602 growth is $30^{\circ} \mathrm{C}$; however, it can tolerate higher temperatures which are desirable, since they favor the saccharification stage with the enzymatic extract NS 22192. Therefore, the yeast was grown at 30 (optimum temperature), 38 and $42{ }^{\circ} \mathrm{C}$. Yeast growth was evaluated by the cell density measured by spectrophotometry at $540 \mathrm{~nm}$. Fig. 1 shows the cell density profile in the first $8 \mathrm{~h}$ at each temperature. Two growth stages of yeast growth were observed: lag phase $(0-2 \mathrm{~h})$ and exponential growth phase $(2-8 \mathrm{~h})$. Cell density in the culture broth was higher at $30^{\circ} \mathrm{C}$ and lower at $42{ }^{\circ} \mathrm{C}$. The specific growth rate $(\mu)$ was determined in exponential growth phase for

Table 1

Chemical composition of primary sludge and unbleached pulp.

\begin{tabular}{|c|c|c|c|c|c|}
\hline \multirow{2}{*}{$\begin{array}{l}\text { Lignocellulosic } \\
\text { material }\end{array}$} & \multirow{2}{*}{$\begin{array}{l}\text { Pulp } \\
\text { mill } \\
\text { code }\end{array}$} & \multirow{2}{*}{$\begin{array}{l}\text { Total } \\
\text { solids,\% }\end{array}$} & \multicolumn{3}{|c|}{ Component,\% (dry weight basis) } \\
\hline & & & $\begin{array}{l}\text { Total } \\
\text { lignin }\end{array}$ & Total ash & Carbohydrates \\
\hline \multirow[t]{3}{*}{ Primary sludge } & A & $22.1 \pm 0.1$ & $2.9 \pm 0.3$ & $38.6 \pm 0.5$ & $58.5 \pm 0.9$ \\
\hline & B & $41.4 \pm 0.1$ & $2.7 \pm 0.6$ & $27.5 \pm 1.2$ & $69.8 \pm 1.9$ \\
\hline & $\mathrm{C}$ & $19.0 \pm 0.1$ & $2.3 \pm 0.1$ & $16.7 \pm 0.7$ & $81.0 \pm 0.8$ \\
\hline $\begin{array}{l}\text { Unbleached } \\
\text { pulp }\end{array}$ & & $29.9 \pm 0.2$ & $2.1 \pm 0.0$ & $0.7 \pm 0.4$ & $97.2 \pm 0.1$ \\
\hline
\end{tabular}

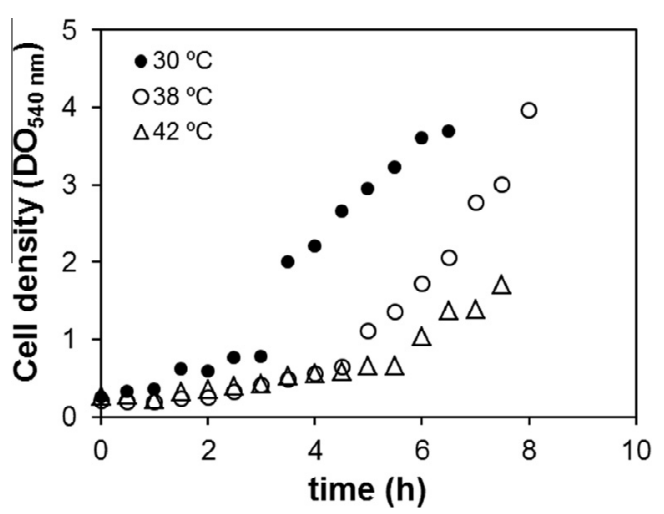

Fig. 1. Growth profiles of S. cerevisiae ATCC 26602 at different temperatures.

each temperature: $0.44 \mathrm{~h}^{-1}$ at $30^{\circ} \mathrm{C}, 0.47 \mathrm{~h}^{-1}$ at $38^{\circ} \mathrm{C}$ and $0.29 \mathrm{~h}^{-1}$ at $42{ }^{\circ} \mathrm{C}$.

Similar values and trend with temperature increase were obtained by Woo et al. (2014) for specific growth rates of S. cerevisiae during ethanol fermentation at high glucose concentration: $0.49,0.45,0.30$ and $0.12 \mathrm{~h}^{-1}$, respectively at $30,38,40$ and $42{ }^{\circ} \mathrm{C}$. Moreover, the authors conclude that the synergistic effects of heat, acetic acid, and ethanol led to reduction of cell growth and ethanol production rates (Woo et al., 2014). Therefore, SSF experiments were carried out at $38{ }^{\circ} \mathrm{C}$ in this work, recognized as a temperature of compromise between the enzymatic hydrolysis and the fermentation process.

\subsection{SSF experiments}

\subsubsection{Effect of sterilization and glucose supplement}

SSF of both primary sludge A (with higher ash and lower carbohydrates) and unbleached pulp (very high carbohydrate content with no ash) was performed with NS 22192 ( $35 \mathrm{FPU}_{\mathrm{CH}}^{-1}$ ) and $S$. cerevisiae ATCC 26602, in fed-batch conditions, to study the effect of sterilization and the addition of a glucose supplement. The fedbatch operation consisted in $50 \mathrm{~g} \mathrm{~L}^{-1}$ of carbohydrates added at $\mathrm{t}=0 \mathrm{~h}$, plus two more equal additions (equivalent to $50 \mathrm{~g} \mathrm{~L}^{-1}$ each) after 24 and $53.5 \mathrm{~h}$.

Table 2 shows the values of ethanol produced in the time course of the SSF, as well as of yield and productivity, for all 6 assays: SSF 1 and 3 were carried out with a glucose supplement; SSF 1, 2 and 5 were performed with sterilization; SSF 3, 4 and 6 were prepared without sterilization; primary sludge A was used in assays 1 to 4 , whilst unbleached pulp was utilized in assays 5 and 6 . The differences registered between the SSF with a glucose supplement (1 and 3 ) and the corresponding ones without that supplement (2 and 4 ) are very small. Therefore, the glucose addition as a promoting agent to yeast growth is not mandatory.

In general, SSF was carried out with sterilized material (1,2 and 5 ). Table 2 shows that slightly higher ethanol concentration, yield and productivity were achieved in the SSF assays with previously sterilized material, compared with the corresponding ones without sterilization (i.e., 1 vs. 3; 2 vs. 4; 5 vs. 6). Small differences were obtained for the three parameters evaluated, either within the experiments with primary sludge (A) or within the experiments with unbleached pulp. Also similar HPLC chromatograms were obtained with no atypical by-products detected, and no contamination was observed.

The removal of the sterilization step from the overall process can be considered, with reduction of both energy costs and overall process time, and also to avoid an eventual degradation of nutritive broth to the yeast. This can compensate some loss in the SSF effi- 
Table 2

Ethanol concentration (EtOH), yield (Y) and productivity $(\mathrm{P})$ obtained in the time course of fed-batch SSF of primary sludge (A) and unbleached pulp.

\begin{tabular}{|c|c|c|c|c|c|c|c|c|c|}
\hline Assay & Time, (h) & 5.5 & $24^{*}$ & 29.5 & 48 & $53.5^{*}$ & 72 & 77.5 & 148 \\
\hline \multirow[t]{3}{*}{1} & EtOH, $\left(\mathrm{g} \mathrm{L}^{-1}\right)$ & 2.9 & 19.1 & 23.6 & 27.8 & 27.6 & 33.4 & 31.4 & 31.4 \\
\hline & $\mathrm{Y},(\%)$ & 10.3 & 67.9 & 42.0 & 49.4 & 49.0 & 39.6 & 37.2 & 37.3 \\
\hline & $\mathrm{P},\left(\mathrm{g} \mathrm{L}^{-1} \mathrm{~h}^{-1}\right)$ & 0.53 & 0.80 & 0.80 & 0.58 & 0.52 & 0.46 & 0.40 & 0.21 \\
\hline \multirow[t]{3}{*}{2} & EtOH, $\left(\mathrm{g} \mathrm{L}^{-1}\right)$ & 2.5 & 19.5 & 23.4 & 27.6 & 28.5 & 31.0 & 30.2 & 31.8 \\
\hline & $\mathrm{Y},(\%)$ & 9.0 & 69.3 & 41.6 & 49.0 & 50.7 & 36.8 & 35.8 & 37.7 \\
\hline & $\mathrm{P},\left(\mathrm{g} \mathrm{L}^{-1} \mathrm{~h}^{-1}\right)$ & 0.46 & 0.81 & 0.79 & 0.57 & 0.53 & 0.43 & 0.39 & 0.22 \\
\hline \multirow[t]{3}{*}{3} & EtOH, $\left(\mathrm{g} \mathrm{L}^{-1}\right)$ & 2.3 & 17.1 & 23.1 & 24.1 & 24.5 & 27.6 & 26.9 & 29.3 \\
\hline & $\mathrm{Y},(\%)$ & 8.0 & 60.7 & 41.0 & 42.8 & 43.5 & 32.7 & 31.9 & 34.7 \\
\hline & $\mathrm{P},\left(\mathrm{g} \mathrm{L}^{-1} \mathrm{~h}^{-1}\right)$ & 0.41 & 0.71 & 0.78 & 0.50 & 0.46 & 0.38 & 0.35 & 0.20 \\
\hline \multirow[t]{3}{*}{4} & EtOH, $\left(\mathrm{g} \mathrm{L}^{-1}\right)$ & 2.5 & 17.2 & 24.2 & 25.5 & 26.4 & 29.1 & 27.7 & 27.9 \\
\hline & $\mathrm{Y},(\%)$ & 9.0 & 61.1 & 43.0 & 45.3 & 47.0 & 34.5 & 32.8 & 33.1 \\
\hline & $\mathrm{P},\left(\mathrm{g} \mathrm{L}^{-1} \mathrm{~h}^{-1}\right)$ & 0.46 & 0.72 & 0.82 & 0.53 & 0.49 & 0.40 & 0.36 & 0.19 \\
\hline \multirow[t]{3}{*}{5} & EtOH, $\left(\mathrm{g} \mathrm{L}^{-1}\right)$ & 2.0 & 20.4 & 20.2 & 35.1 & 36.4 & 46.1 & 43.1 & 42.4 \\
\hline & $\mathrm{Y},(\%)$ & 7.2 & 72.0 & 35.6 & 61.9 & 64.1 & 54.1 & 50.6 & 49.8 \\
\hline & $\mathrm{P},\left(\mathrm{g} \mathrm{L}^{-1} \mathrm{~h}^{-1}\right)$ & 0.37 & 0.85 & 0.69 & 0.73 & 0.68 & 0.64 & 0.56 & 0.29 \\
\hline \multirow[t]{3}{*}{6} & $\mathrm{EtOH},\left(\mathrm{g} \mathrm{L}^{-1}\right)$ & 1.5 & 19.0 & 19.2 & 32.4 & 33.1 & 43.7 & 40.1 & 43.4 \\
\hline & $\mathrm{Y},(\%)$ & 5.2 & 67.0 & 33.7 & 57.0 & 58.2 & 51.3 & 47.1 & 43.4 \\
\hline & $\mathrm{P},\left(\mathrm{g} \mathrm{L}^{-1} \mathrm{~h}^{-1}\right)$ & 0.27 & 0.79 & 0.65 & 0.67 & 0.62 & 0.61 & 0.52 & 0.25 \\
\hline
\end{tabular}

Before carbohydrates addition.

ciency. Ma et al. (2007) investigated the ethanol production from non-sterilized kitchen refuse in repeated-batch culturing with $S$. cerevisiae ATCC 26602. No contamination had occurred during the long-term fermentation, mainly because of naturally acidic $\mathrm{pH}$ of the kitchen refuse medium. According to Ma et al. (2007), $\mathrm{pH}$ control and medium sterilization can be avoided allowing lower ethanol production cost in pilot applications. Kopsahelis et al. (2012) also used non-sterilized molasses as feedstock in continuous ethanol production with immobilized $S$. cerevisiae. No additional treatments were applied to prevent contamination and higher ethanol concentrations (up to $51 \mathrm{~g} \mathrm{~L}^{-1}$ ) were achieved with non-sterilized molasses, compared to sterilized molasses (up to $46 \mathrm{~g} \mathrm{~L}^{-1}$ ethanol).

It is commonly observed that the ethanol concentration reaches a plateau for longer reaction times or even decreases slightly. Some hypotheses can be pointed out for this behavior, namely i) slow ethanol evaporation for long SSF periods; ii) use of ethanol by $S$. cerevisiae ATCC 26602 as carbon and energy source, when simple sugars are missing; iii) use of ethanol as co-substrate in xylose reduction to xylitol (confirmed in HPLC chromatograms, data not shown) also reported in the literature (Latif and Rajoka, 2001).

\subsubsection{Effect of enzyme dosage reduction}

Enzyme costs have a major contribution for overall process costs. In an industrial SSF, enzyme and cell concentrations should be appropriately balanced in order to minimize costs for enzyme and yeast acquisition or production (Olofsson et al., 2008). The fed-batch SSF of unbleached pulp and primary sludge (C) (lower ash and higher carbohydrates) were carried out with enzyme dosages of 35, 25 and 15 FPU $\mathrm{g}_{\mathrm{CH}}^{-1}$. The ethanol produced is showed in Fig. 2. Ethanol production profiles were quite similar until $75 \mathrm{~h}$ in the fed-batch SSF of unbleached pulp (Fig. 2a). During the period of $150 \mathrm{~h}$, no major differences were observed in the fed-batch SSF of primary sludge (sample $\mathrm{C}$ ) when enzyme dosage was changed (Fig. 2).

Table 3 also shows the similarities between the maximum ethanol produced in these studies, as well as the corresponding yield (measured as percentage of the theoretical yield) and productivity. Therefore, SSF of primary sludge or unbleached pulp can be carried out with an enzyme dosage of 15 FPU g $g_{C H}^{-1}$ of NS 22192. An ethanol concentration of $44.4 \mathrm{~g} \mathrm{~L}^{-1}$ was produced in the fed-batch SSF of $150 \mathrm{~g} \mathrm{~L}^{-1}$ of carbohydrates of unbleached pulp, with a productivity of $0.57 \mathrm{~g} \mathrm{~L}^{-1} \mathrm{~h}^{-1}$ and a carbohydrate-to-ethanol conversion of $52.1 \%$ (Table 3 ). The same amount of carbohydrates from primary sludge (C) was converted to $33.3 \mathrm{~g} \mathrm{~L}^{-1}$ of ethanol, in the same SSF conditions. Ethanol yield and productivity were $39.1 \%$ and $0.43 \mathrm{~g} \mathrm{~L}^{-1} \mathrm{~h}^{-1}$, respectively (Table 3).

In the present work, the differences registered were not so significant, compared to other works. Different loadings of cellulase to hydrolyze lignocellulosic wastes, ranging from 45 to $5 \mathrm{FPU} \mathrm{g}^{-1}$ (grams of dry material, cellulose or glucan), can be found in several reports with decreasing of ethanol concentration and yield (Ballesteros et al., 2002; Kádár et al., 2004; Faga et al., 2010; Chen et al., 2012; Kang et al., 2011; Boshoff et al., 2016; Guan et al., 2016). In comparison with our study, about one half of the ethanol concentration was obtained by Ballesteros et al. (2002), in the fed-batch SSF of recycled-paper-derived material using $15 \mathrm{FPU} \mathrm{g}^{-1}$ of Celluclast $1.5 \mathrm{~L}$ and the thermotolerant yeast Kluyveromyces marxianus CACT 10875 at $42{ }^{\circ} \mathrm{C}$. In contrast, higher yield was obtained but a supplement of enzyme was always added by the authors at the same time as the fresh substrate addition, whilst in the present work only an initial enzyme loading was performed. A higher solids content was also used in our work (18.5\%), which led to higher ethanol concentration, but lower yield. In fact, Boshoff et al. (2016) reported a decrease in glucose yield with an increase in solid loading at all the enzyme dosages tested with two different substrates (corrugated recycle paper sludge and paper sludge from virgin pulp). The SSF of paper sludge from virgin pulp in fed-batch culture with a solids content of $18 \%$, at an enzyme loading of $20 \mathrm{FPU} \mathrm{g}^{-1}$, using S. cerevisiae MH1000, has led to an ethanol concentration of $34.2 \mathrm{~g} \mathrm{~L}^{-1}$, a yield of $66.9 \%$ and a productivity of $0.23 \mathrm{~g} \mathrm{~L}^{-1} \mathrm{~h}^{-1}$. Similar ethanol concentrations were achieved in the present work, from the SSF of primary sludge at analogous solid loading (Table 3 ) with lower yield, but higher productivity. Due to the different composition of both substrates and enzymatic extracts, comparison of fermentable parameters from literature must be carefully done.

\subsubsection{Fed-batch vs. batch operation}

3.4.3.1. Fed-batch with $5 \mathrm{FPU} \mathrm{g}_{\mathrm{CH}}^{-1}$. SSF of primary sludge samples from two different sources, in fed-batch conditions with NS 22192 and S. cerevisiae ATCC 26602, are compared in Fig. 3. The enzyme loading at $\mathrm{t}=0$ was $15 \mathrm{FPU} \mathrm{g}_{\mathrm{CH}}^{-1}$ considering the initial carbohydrate content of $50 \mathrm{~g} \mathrm{~L}^{-1}$. Since two carbohydrates feeds of 

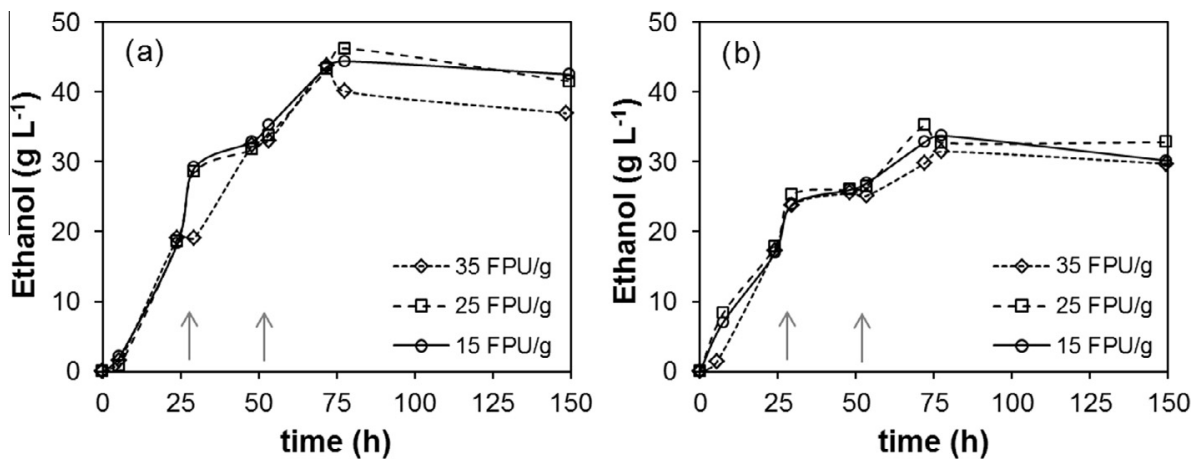

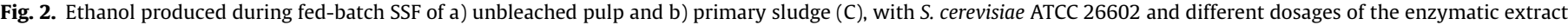
NS 22192. The vertical arrows correspond to carbohydrates feeding.

Table 3

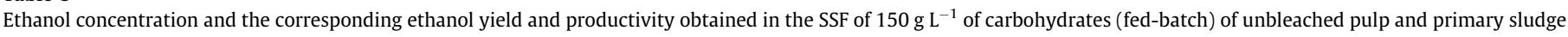
(C), with S. cerevisiae ATCC 26602 and different dosages of the enzymatic extract NS 22192.

\begin{tabular}{|c|c|c|c|c|c|c|}
\hline Lignocellulosic biomass & Total Solids added (\%) & Enzyme dosage (FPU g g & Time $(\mathrm{h})$ & {$[\mathrm{EtOH}]\left(\mathrm{g} \mathrm{L}^{-1}\right)$} & $\mathrm{Y}(\%)$ & $\mathrm{P}\left(\mathrm{g} \mathrm{L}^{-1} \mathrm{~h}^{-1}\right)$ \\
\hline Unbleached Pulp & 15.4 & $\begin{array}{l}35 \\
25 \\
15\end{array}$ & $\begin{array}{l}72.0 \\
77.5 \\
77.5\end{array}$ & $\begin{array}{l}43.4 \pm 0.4 \\
46.6 \pm 0.5 \\
44.4 \pm 0.0\end{array}$ & $\begin{array}{l}51.3 \pm 0.5 \\
54.7 \pm 0.6 \\
52.1 \pm 0.0\end{array}$ & $\begin{array}{l}0.58 \pm 0.04 \\
0.60 \pm 0.01 \\
0.57 \pm 0.00\end{array}$ \\
\hline Primary sludge (C) & 18.5 & $\begin{array}{l}35 \\
25 \\
15\end{array}$ & $\begin{array}{l}77.5 \\
72.0 \\
77.5\end{array}$ & $\begin{array}{l}31.2 \pm 0.4 \\
31.9 \pm 1.1 \\
33.3 \pm 0.6\end{array}$ & $\begin{array}{l}36.7 \pm 0.4 \\
37.5 \pm 1.3 \\
39.1 \pm 0.7\end{array}$ & $\begin{array}{l}0.42 \pm 0.02 \\
0.41 \pm 0.01 \\
0.43 \pm 0.01\end{array}$ \\
\hline
\end{tabular}
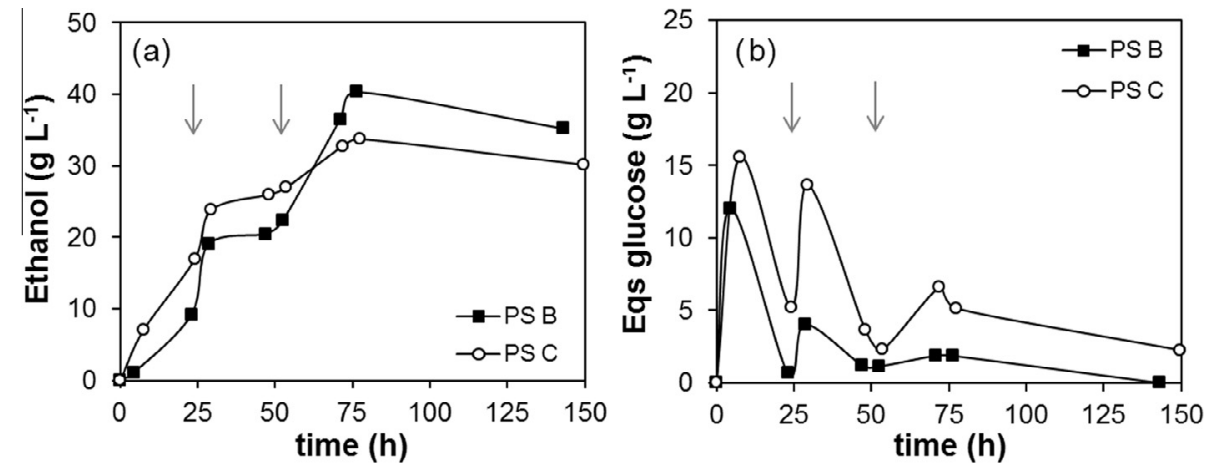

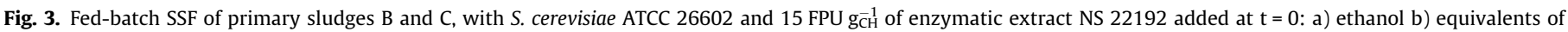
glucose. The vertical arrows correspond to carbohydrates feeding of $50 \mathrm{~g} \mathrm{~L}^{-1}$ giving a total amount of $150 \mathrm{~g} \mathrm{~L}^{-1}$.

Table 4

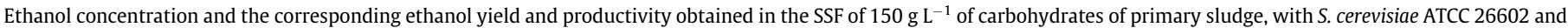
15 FPU $\mathrm{g}_{\mathrm{CH}}^{-1}$ of the enzymatic extract NS 22192

\begin{tabular}{|c|c|c|c|c|c|c|c|}
\hline SSF conditions & Primary sludge & Total solids (\%) & Total effective enzyme dosage (FPU $\mathrm{g}_{\mathrm{CH}}^{-1}$ ) & Time (h) & {$[\mathrm{EtOH}]\left(\mathrm{g} \mathrm{L}^{-1}\right)$} & $\mathrm{Y}(\%)$ & $\mathrm{P}\left(\mathrm{g} \mathrm{L}^{-1} \mathrm{~h}^{-1}\right)$ \\
\hline \multirow[t]{2}{*}{ Fed-batch } & B & 21.7 & 5 & 76.5 & $39.7 \pm 0.9$ & $46.4 \pm 1.0$ & $0.52 \pm 0.02$ \\
\hline & $\mathrm{C}$ & 18.5 & & 77.5 & $33.3 \pm 0.6$ & $39.1 \pm 0.7$ & $0.43 \pm 0.01$ \\
\hline \multirow[t]{4}{*}{ Batch } & B & 21.7 & 5 & 53.3 & $41.7 \pm 1.2$ & $48.9 \pm 1.4$ & $0.78 \pm 0.03$ \\
\hline & $\mathrm{C}$ & 18.5 & & 52.5 & $41.9 \pm 1.1$ & $49.4 \pm 1.3$ & $0.80 \pm 0.03$ \\
\hline & B & 21.7 & 15 & 53.3 & $54.6 \pm 0.0$ & $64.0 \pm 0.0$ & $1.02 \pm 0.00$ \\
\hline & $\mathrm{C}$ & 18.5 & & 52.5 & $44.9 \pm 0.4$ & $52.8 \pm 0.5$ & $0.86 \pm 0.01$ \\
\hline
\end{tabular}

$50 \mathrm{~g} \mathrm{~L}^{-1}$ each were added, without further enzyme loading, the effective overall enzyme loading was $5 \mathrm{FPU} \mathrm{g}_{\mathrm{CH}}^{-1}$ in fed-batch conditions. Fig. 3a shows ethanol profiles obtained in the time-course of the experiments. Despite the higher ash content for the same amount of carbohydrates, the highest ethanol concentration was obtained for primary sludge B at $\sim 77 \mathrm{~h}$. The carbohydrates from primary sludge $\mathrm{B}$ were converted to $39.7 \mathrm{~g} \mathrm{~L}^{-1}$ of ethanol, corresponding to a production rate of $0.52 \mathrm{~g} \mathrm{~L}^{-1} \mathrm{~h}^{-1}$ and to an ethanol yield of $46.4 \%$ (Table 4). An ethanol concentration of $33.3 \mathrm{~g} \mathrm{~L}^{-1}$ was produced from the carbohydrates of primary sludge $C$, with a conversion yield of $39.1 \%$ and a productivity of $0.43 \mathrm{~g} \mathrm{~L}^{-1} \mathrm{~h}^{-1}$ (Table 4). According to Fig. 3b, the concentration of reducing sugars available in the SSF broths increases until $8 \mathrm{~h}$ (when enzymatic hydrolysis was the prominent reaction); afterwards it decreases, due to ethanol production, until the reactor was fed with a second carbohydrates load. After $25 \mathrm{~h}$ the same pattern described is 


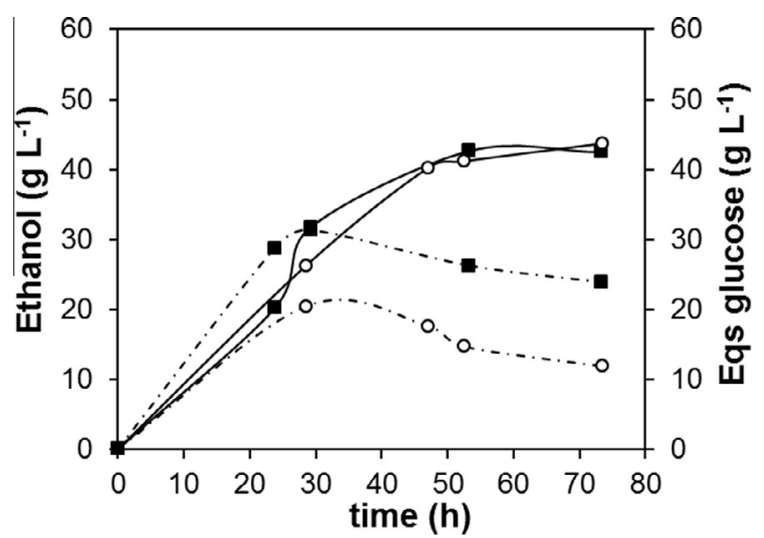

Fig. 4. Batch SSF of primary sludge B (black squares) and C (white circles), with $S$. cerevisiae ATCC 26602 and 5 FPU g $_{\mathrm{CH}}^{-1}$ of enzymatic extract NS 22192 (ethanol: full lines; equivalents of glucose: dotted lines).

observed. It becomes unnecessary to extend the SSF beyond $78 \mathrm{~h}$ of reaction (in the conditions used in this work), because although small amounts of reducing sugars are still available the concentration of ethanol did not increase.

3.4.3.2. Batch with $5 \mathrm{FPU} \mathrm{g}_{\mathrm{CH}}^{-1}$. In a different set of experiments, batch SSF was tested on primary sludges B and C with S. cerevisiae ATCC 26602 and cellulase NS 22192 - Fig. 4. The enzyme loading at $\mathrm{t}=0$ was $5 \mathrm{FPU} \mathrm{g}_{\mathrm{CH}}^{-1}$, considering the initial carbohydrate content of $150 \mathrm{~g} \mathrm{~L}^{-1}$

The bioconversion of primary sludge $B$ and $C$ produced similar ethanol concentrations ( 41.7 and $41.9 \mathrm{~g} \mathrm{~L}^{-1}$, respectively). Carbohydrates were transformed to ethanol with a conversion yield of 48.9 and $49.4 \%$, whereas ethanol productivity was 0.78 and $0.80 \mathrm{~g} \mathrm{~L}^{-1} \mathrm{~h}^{-1}$, respectively, as shown in Table 4. However, a reducing sugars concentration of $\sim 25 \mathrm{~g} \mathrm{~L}^{-1}$, expressed as equivalents of glucose (Fig. 4), remained in the SSF broth for primary sludge B, whilst for primary sludge $C \sim 15 \mathrm{~g} \mathrm{~L}^{-1}$ of the available fermentable sugars were not metabolized by S. cerevisiae ATCC 26602.

3.4.3.3. Batch with $15 \mathrm{FPU} \mathrm{g}_{\mathrm{CH}}^{-1}$. A total carbohydrate content of $150 \mathrm{~g} \mathrm{~L}^{-1}$ (from primary sludge B or C) was initially loaded with 15 FPU g g -1 of NS 22192 and S. cerevisiae ATCC 26602 - Fig. 5. In comparison with Fig. 4, the higher enzyme loading promotes carbohydrates hydrolysis. In this batch SSF operation, a higher average content of glucose improves ethanol production (Fig. 5); however,

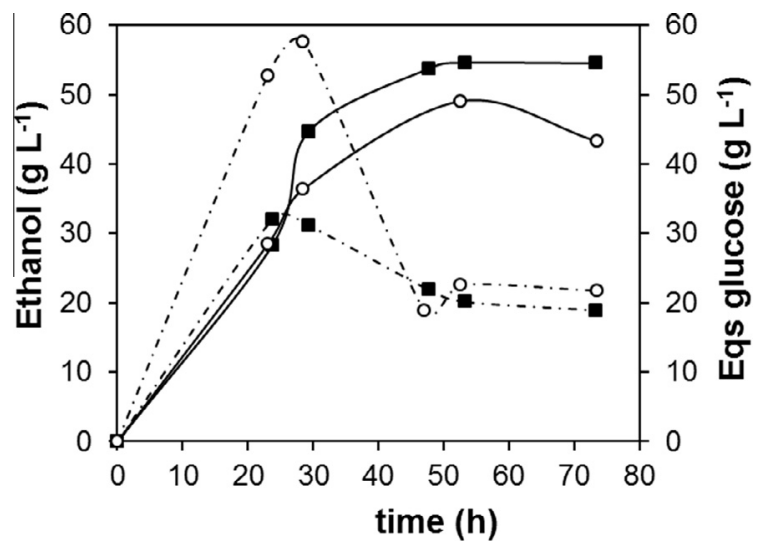

Fig. 5. Batch SSF of primary sludge B (black squares) and C (white circles), with $S$. cerevisiae ATCC 26602 and $15 \mathrm{FPU} \mathrm{g}_{\mathrm{CH}}^{-1}$ of enzymatic extract NS 22192 (ethanol: full lines; equivalents of glucose: dotted lines). high concentration of ethanol can inhibit the yeast metabolism (Fig. 5). In fact, despite the significant quantity of reducing sugars still available at the end $\left(\sim 20 \mathrm{~g} \mathrm{~L}^{-1}\right)$, no more ethanol was produced, as observed in Fig. 5.

Carbohydrates from primary sludge $\mathrm{B}$ were converted to $54.6 \mathrm{~g} \mathrm{~L}^{-1}$ of ethanol after $53 \mathrm{~h}$ of batch SSF, with an ethanol yield and productivity of $64 \%$ and $1.02 \mathrm{~g} \mathrm{~L}^{-1} \mathrm{~h}^{-1}$, respectively (Table 4). The corresponding values for primary sludge $\mathrm{C}$ were $44.9 \mathrm{~g} \mathrm{~L}^{-1}$, $52.8 \%$ and $0.86 \mathrm{~g} \mathrm{~L}^{-1} \mathrm{~h}^{-1}$, respectively.

In general, higher SSF efficiency was obtained when primary sludge B was used as feedstock, independently of the fed conditions (fed-batch or batch). Concerning total solids and carbohydrates contents (see Table 1), a less amount of primary sludge B (as received) was needed to provide the carbohydrates concentration of $150 \mathrm{~g} \mathrm{~L}^{-1}$, compared to primary sludge $C$ (as received). Thus, lower mixing difficulties were observed in the SSF with primary sludge $B$, increasing the process efficiency. Considering the primary sludges chemical composition, presented in Table 1, the maximum possible solid loading is 41.4 and $19.0 \%$, for sample B and C, respectively, unless an additional step of water evaporation or pressing is applied. The solids content of primary sludge $C$, used in this work, is near its maximum possible value and the suspension presented a highly viscous nature. Highly viscous slurries causes mixing difficulties, ineffective mass and heat transfer, lower water activity and ineffective hydrolysis, which explains why ethanol yields were, generally, lower in the SSF of primary sludge C.

Other authors have reported that digestibility, water holding capacity and viscosity were the main factors affecting high solid fed-batch SSF of primary sludge (Boshoff et al., 2016). Moreover, the primary sludge that resulted in highly viscous slurries was also converted into lower ethanol concentrations and, consequently, lower yields were obtained.

Fed-batch SSF is usually considered to address the problems associated with high solids and to increase ethanol concentrations. In the SSF of untreated primary sludge performed by Kang et al. (2010) with S. cerevisiae ATCC 200062 and $15 \mathrm{FPU} \mathrm{g}^{-1}$-glucan, an ethanol concentration of $25.5 \mathrm{~g} \mathrm{~L}^{-1}$ was obtained, with a conversion yield of $75 \%$, based on glucan content in the sludge $(6 \% \mathrm{w} /$ w). In a three-feed SSF, ethanol increased to $45 \mathrm{~g} \mathrm{~L}^{-1}$, produced after $90 \mathrm{~h}$ of process and with a lower conversion yield (68\%).

In the present study, batch and fed-batch conditions were compared using the same carbohydrate loading $\left(150 \mathrm{~g} \mathrm{~L}^{-1}\right)$ and total effective enzyme dosage. Contrarily to the results found in the literature, the batch SSF produced higher ethanol concentration, with higher ethanol yield and productivity, independently of the primary sludge used. Nevertheless, it should be pointed out that the same high solids content (18.5 or $21.7 \%$ ) was used in batch and fed-batch SSF, rarely reported in literature. In batch operation, the liquefaction of the reaction mixture took longer than the fedbatch operation: the first samples were withdrawn at 6 and $24 \mathrm{~h}$, in the fed-batch and batch assays, respectively. There are some questions to consider why batch SSF yield was higher than fedbatch SSF yield, even with initial higher mixing difficulties. Some authors added enzymes with each substrate addition to maintain a constant enzyme-to-substrate ratio in the enzymatic hydrolysis or SSF of cellulosic biomass in fed-batch conditions (Kang et al., 2011; Cardona et al., 2015). Cardona et al. (2015) also pointed that the timing of enzyme addition, relative to feedstock addition, can also influence the process efficiency. Therefore, the timing of carbohydrates and enzyme additions in fed-batch SSF will be considered in further studies to better evaluate this process.

During the SSF experiments, $\mathrm{pH}$ was also monitored. Its value was near 6 with small oscillations. Acetic acid (a by-product detected by HPLC, data not shown) and $\mathrm{CO}_{2}$ released may have partially neutralized $\mathrm{CaCO}_{3}$ and act as a buffer to decrease and stabilize $\mathrm{pH}$ (existing $\mathrm{CaCO}_{3}$ in primary sludge is responsible for its 
alkalinity, $\mathrm{pH} \sim 8$ ). The benefits of the buffering effect of $\mathrm{CaCO}_{3}$ has been shown in other studies, in which SSF of paper mill sludge was performed with no chemical pretreatment and $\mathrm{pH}$ control to produce acetone-butanol-ethanol solvents (Guan et al., 2016). Nevertheless, the authors state that the paper sludge needs to be partially de-ashed to improve the enzymatic digestibility. Other authors (Kang et al., 2011; Chen et al., 2014) de-ashed paper sludge before its bioconversion, using mechanical fractionation or carbon dioxide bubbling, improving final conversion yields. For instance, Kang et al. (2011) reported an improvement in ethanol concentration from $45 \mathrm{~g} \mathrm{~L}^{-1}$ with untreated sludge (three-feed SSF) to $60 \mathrm{~g} \mathrm{~L}^{-1}$ (four-feed SSF) with de-ashed primary sludge. However, the overall ethanol yield just slightly increased, 68 to 70\% (based on glucan).

The enzymatic extract NS 22192 is similar to Cellic CTec2, whose maximal enzymatic saccharification was found by Lan et al. (2013) to occur at pH 5.2-6.2 over lignocellulosic substrates, instead of $\mathrm{pH} 4.8-5.0$ over pure cellulosic substrates, used in the majority of the literature found. The $\mathrm{pH}$ value near 6 observed for the SSF experiments of pulp sludge in the present work is within this optimal range.

\section{Conclusions}

Primary sludges, from three pulp mills and without pretreatment, were successfully used in SSF to produce ethanol using $150 \mathrm{~g} \mathrm{~L}^{-1}$ of carbohydrates. With an enzyme dosage of $5 \mathrm{FPU} \mathrm{g} \mathrm{C}_{\mathrm{CH}}^{-1}$, higher ethanol concentration, yield and productivity were achieved in batch conditions (41.7 $\mathrm{g} \mathrm{L}^{-1}, 48.9 \%$ and $0.78 \mathrm{~g} \mathrm{~L}^{-1} \mathrm{~h}^{-1}$, respectively) compared with fed-batch, despite of initial mixing difficulties. The corresponding values were $54.6 \mathrm{~g} \mathrm{~L}^{-1}, 64.0 \%$ and $1.02 \mathrm{~g} \mathrm{~L}^{-1} \mathrm{~h}^{-1}$ when enzyme dosage was increased to $15 \mathrm{FPU} \mathrm{g}-1$ in batch SSF. Sterilization removal can be considered, decreasing energy requests and overall process costs and time.

\section{Acknowledgements}

This work has been framed under the Initiative Energy for Sustainability of the University of Coimbra and supported by the project Energy and Mobility for Sustainable Regions - EMSURE (CENTRO-07-0224-FEDER-002004). Cátia Mendes is grateful for the research Grant provided. The funding agency had no involvement in the study design, in the collection, analysis and interpretation of data, in the writing of the report or in the decision to submit the article for publication.

\section{References}

Balat, M., 2011. Production of bioethanol from lignocellulosic materials via the biochemical pathway: a review. Energy Convers. Manage. 52, 585-875.

Ballesteros, M., Oliva, J.M., Manzanares, P., Negro, M.J., Ballesteros, I., 2002. Ethanol production from paper material using a simultaneous saccharification and fermentation system in a fed-batch basis. World J. Microbiol. Biotechnol. 18 559-561.

Ballesteros, M., Oliva, J.M., Negro, M.J., Manzanaresm, P., Ballesteros, I., 2004 Ethanol from lignocellulosic materials by a simultaneous saccharification and fermentation process (SSF) with Kluyveromyces marxianus CECT 10875. Process Biochem. 39, 1843-1848.

Boshoff, S., Gottumukkala, D., van Rensburg, E., Görgens, J., 2016. Paper sludge (PS) to bioethanol: Evaluation of virgin and recycle mill sludge for low enzyme, high-solids fermentation. Bioresour. Technol. 203, 103-111.

Budhavaram, N.K., Fan, Z., 2009. Production of lactic acid from paper sludge using acid-tolerant, thermofilic Bacillus coagulan strains. Bioresour. Technol. 100, 5966-5972.

Barnett, J.A., 2003. A history of research on yeasts 5: the fermentation pathway Yeast 20, 509-543.

Cardona, M.J., Tozzi, E.J., Karuna, N., Jeoh, T., Powell, R.L., McCarthy, M.J., 2015. A process for energy-efficient high-solids fed-batch enzymatic liquefaction of cellulosic biomass. Bioresour. Technol. 198, 488-496.
Cavka, A., Alriksson, B., Rose, S.H., van Zyl, W.H., Jönsson, L.J., 2014. Production of cellulosic ethanol and enzyme from waste fiber sludge using SSF, recycling of hydrolytic enzymes and yeast, and recombinant cellulase-producing Aspergillus niger. J. Ind. Microbiol. Biotechnol. 41, 1191-1200.

Chen, H., Venditti, R.A., Jameel, H., Park, S., 2012. Enzymatic hydrolysis of recovered office printing paper with low enzyme dosages to produce fermentable sugars. Appl. Biochem. Biotechnol. 166, 1121-1137.

Chen, H., Han, Q., Daniel, K., Venditti, R., Jameel, H., 2014. Conversion of industrial paper sludge to ethanol: fractionation of sludge and its impact. Appl. Biochem. Biotechnol. 174, 2096-2113.

Dwiarti, L., Boonchird, C., Harashma, S., Park, E.Y., 2012. Simultaneous saccharification and fermentation of paper sludge without pretreatment using cellulase from Acremonium cellulolyticus and thermotolerant Saccharomyces cerevisiae. Biomass Bioenergy 42, 114-122.

Faga, B.A., Wilkins, M.R., Banat, I.M., 2010. Ethanol production through simultaneous saccharification and fermentation of switchgrass using Saccharomyces cerevisiae D5A and thermotolerant Kluyveromyces marxianus IMB strains. Bioresour. Technol. 101, 2273-2279.

Fan, Z., Lynd, L.R., 2007. Conversion of paper sludge to ethanol. I: impact of feeding frequency and mixing energy characterization. Bioprocess Biosyst. Eng. 30, 2734.

Ferreira, V., Faber, M.O., Mesquita, S.S., Pereira Jr., N., 2010. Simultaneous saccharification and fermentation process of different cellulosic substrates using a recombinant Saccharomyces cerevisiae harbouring the $\beta$-glucosidase gene. Electron. J. Biotechnol. 13 (2).

Guan, W., Shi, S., Tu, M., Lee, Y.Y., 2016. Acetone-butanol-ethanol production from Kraft paper mill sludge by simultaneous saccharification and fermentation. Bioresour. Technol. 200, 713-721.

Gurram, R.N., Al-Shannag, M., Lecher, N.J., Duncan, S.M., Singsaas, E.L., Alasrawi, M., 2015. Bioconversion of paper mill sludge to bioethanol in the presence of accelerants or hydrogen peroxide pretreatment. Bioresour. Technol. 192, 529539.

Kádár, Zs., Szengyel, Zs., Réczey, K., 2004. Simultaneous saccharification and fermentation (SSF) of industrial wastes for the production of ethanol. Ind. Crops Prod. 20, 103-110.

Kang, L., Wang, W., Lee, Y.Y., 2010. Bioconversion of kraft paper mill sludges to ethanol by SSF and SSCF. Appl. Biochem. Biotechnol. 161, 53-66.

Kang, L., Wang, W., Pallapolu, V., Lee, Y., 2011. Enhanced ethanol production from de-ashed paper sludge by simultaneous saccharification and fermentation and simultaneous saccharification and co-fermentation. Bioresources 6, 3791-3808.

Kopsahelis, N., Bosnea, L., Bekatorou, A., Tzia, C., Kanellaki, M., 2012. Alcohol production from sterilized and non-sterilized molasses by Sacharomyces cerevisiae immobilized on brewer's spent grains in two types of continuous bioreactor systems. Biomass Bioenergy 45, 87-94.

Lan, T.Q., Lou, H., Zhu, J.Y., 2013. Enzymatic saccharification of lignocelluloses should be conducted at elevated pH 5.2-6.2. Bioenergy Res. 6, 476-485.

Latif, F., Rajoka, M.I., 2001. Production of ethanol and xylitol from corn cobs by yeasts. Bioresour. Technol. 77, 57-63.

Li, H., Kim, N.-J., Jiang, M., Kang, J.W., Chang, H.N., 2009. Simultaneous saccharification and fermentation of lignocellulosic residues pretreated with phosphoric acid-acetone for bioethanol production. Bioresour. Technol. 100, 3245-3251.

Lin, Y., Wang, D., Wang, T., 2012. Ethanol production from pulp \& paper sludge and monosodium glutamate waste liquor by simultaneous saccharification and fermentation in batch condition. Chem. Eng. J. 191, 31-37.

Ma, K.D., Wakisaka, M., Kiuchi, T., Praneetrattananon, S., Morimura, S., Kida, K., Shirai, Y., 2007. Repeated-batch ethanol fermentation of kitchen refuse by acidtolerant flocculating yeast under the non-sterilized condition. Jpn. J. Food Eng. $8,275-279$.

Marques, S., Alves, L., Roseiro, J.C., Gírio, F.M., 2008. Conversion of recycled paper sludge to ethanol by SHF and SSF using Pichia stipitis. Biomass Bioenergy 32, 400-406.

Mendes, C.V.T., Rocha, J.M.S., Carvalho, M.G.V.S., 2014. Valorization of residual streams from pulp and paper mills: pretreatment and bioconversion of primary sludge to bioethanol. Ind. Eng. Chem. Res. 53, 19398-19404.

National Renewable Energy Laboratory (NREL), 2008. Laboratory Analytical Procedure (LAP)

Nevoigt, E., 2008. Progress in metabolic engineering of Saccharomyces cerevisiae. Microbiol. Mol. Biol. Rev. 72, 379-412.

Olofsson, K., Bertilsson, M., Lidén, G., 2008. A short review on SSF - an interesting process option for ethanol production from lignocellulosic feedstocks. Biotechnol. Biofuels 1, 7-21.

Park, E.Y., Anh, P.N., Okuda, N., 2004. Bioconversion of waste office paper to L(+)lactic acid by the filamentous fungus Rhizopus oryzae. Bioresour. Technol. 93, $77-83$.

Wang, X., Somg, A., Li, L., Li, X., Zhang, R., Bao, J., 2011. Effect of calcium carbonate in waste office paper on enzymatic hydrolysis efficiency and enhancement procedures. Korean J. Chem. Eng. 28, 550-556.

Woo, J.-M., Yang, K.-M., Kim, S.-U., Blank, L.M., Park, J.-B., 2014. High temperature stimulates acetic acid accumulation and enhances the growth inhibition and ethanol production by Saccharomyces cerevisiae under fermenting conditions. Appl. Microbiol. Biotechnol. 98, 6085-6094.

Zhang, J., Lynd, L.R., 2010. Ethanol production from paper sludge by simultaneous saccharification and co-fermentation using recombinant xylose-fermenting microorganisms. Biotechnol. Bioeng. 107, 235-244. 